\title{
Aflatoxins Contamination of Human Food Commodities Collected from Jeddah Markets, Saudi Arabia
}

\author{
Mahmoud El Tawila ${ }^{1}$, Serdar Sadeq ${ }^{2}$, Alrasheedi Amani Awad ${ }^{3}$, Jamil Serdar ${ }^{4}$, Mohamed Hussein Fahmy Madkour ${ }^{5}$, \\ Mohamed M. Deabes ${ }^{6 *}$ \\ ${ }^{1}$ Department of Environmental Science, Faculty of Meteorology, Environment and Arid land Agriculture, King Abdulaziz \\ University, Jeddah, Saudi Arabia; ${ }^{2}$ Ministry of Health Saudi Arabia, Public Health Ministry of Health, Health Programs and \\ Chronic Disease, Saudi Arabia; ${ }^{3}$ Department of Food Nutrition, Faculty of Home Economics, King Abdulaziz University, Jeddah, \\ Saudi Arabia; ${ }^{4}$ Ministry of Health Saudi Arabia, Alzahir Primary Health Care Centre;Saudi Arabia; ${ }^{5}$ Faculty of Environment and \\ Arid Land Agriculture, King Abdulaziz University, Jeddah, Saudi Arabia; ${ }^{6}$ Department of Food Toxicology and Contaminants, \\ National Research Centre, Dokki, Giza, Egypt
}

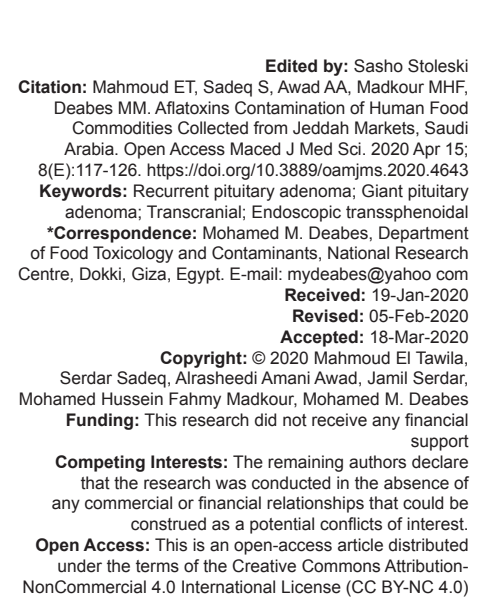

\begin{abstract}
BACKGROUND: Aflatoxins (AFs) are fungal secondary metabolites produced by Aspergillus flavus. They contaminate of dietary food with AFs is a worldwide problem that affects both food safety and agricultural economies.

AIM: The aim of this study was designed to investigate the AFs contents of human food commodities mostly consumed in Jeddah, Saudi Arabia.

METHODS: The study was designed in vitro, contents in six food categories. A total of 288 samples were collected from 78 different markets in Jeddah. AFs were determined by high-performance liquid chromatography with fluorescence detector using immunoaffinity column clean-up.

RESULTS: The results indicated that the incidence rate $27.3 \%$ of nut samples collected from Jeddah, were contaminated with $A F B_{1}, A F B_{2}$. The concentrations of $A F s\left(A F B_{1}, A F B_{2}, A F G_{1}\right.$, and $\left.A F G_{2}\right)$ were ranged from 0.19 $482.4,0.09-3.34,0.19-87.1$, to $0.09-579 \mu \mathrm{g} / \mathrm{kg}$ in the nut samples.

CONCLUSION: The results demonstrate the importance of routine monitoring of AFs contamination in various dry foods for human consumed should be performed regularly and the nuts contained high levels of AFs. The legal
\end{abstract} regulations must be unauthorized for human consumption to control the health risks associated with AFs.

\section{Introduction}

Aflatoxins (AFs) are secondary metabolites produced by fungi of Aspergillus flavus, Aspergillus parasiticus, and Aspergillus nomius that are toxic to humans and animals. AFs are the most important mycotoxins with regard to occurrence, toxicity, and impact on human health and trade in the world [1].

Consumption of mycotoxin contaminated foods has been associated with several cases of human poisoning, or mycotoxicosis, and sometimes resulting in death [2]. The International Agency for Research on Cancer has classified AFB ${ }_{1}$ as a Group I carcinogen, primarily affecting liver [3]. On the other side, the long-term exposure to $\mathrm{AFB}_{1}$ caused genotoxicity and hepatocellular carcinoma [4], [5]. Natural occurrence of $A F$ in nuts has been studied in various countries. According to a report from Mexico, $2.2 \%$ of pistachio nut samples analyzed contained AF higher than
$20 \mathrm{ng} / \mathrm{g}$ [6]. In Sweden, 9.5\% pistachio nut samples contained AFB , higher than $2 \mathrm{ng} / \mathrm{g}$ [7]. According to Ministry of Agriculture and Rural Affairs, Republic of Turkey [8], analysis of 523 pistachio nut samples in Turkey the mean of AFB ranged 1-3.78 $\mathrm{ng} / \mathrm{g}$ and the maximum level $(\mathrm{ML})$ detected was $113 \mathrm{ng} / \mathrm{g}$.

AFs are primarily produced by strains of A. flavus, A. parasiticus, A. nomius [1], Aspergillus pseudotamarii [9], and Aspergillus bombycis [10]. All of these species are found in the soil [1]. The four major AFs commonly isolated from foods and feeds are AFs $\mathrm{B}_{1}, \mathrm{~B}_{2}, \mathrm{G}_{1}$, and $\mathrm{G}_{2}$. A. flavus and A. pseudotamari produce only $B$ AFs. They lack the ability to synthesize $\mathrm{G}$ AFs due to 0.8 - to $1.5-\mathrm{kb}$ deletion in the $28-\mathrm{gene}$ AF biosynthesis cluster [11]. Aspergillus nominus, A. bombycis, and $A$. parasiticus produce all four major AFs. AFs $M_{1}$ and $M_{2}$ are hydroxylated metabolites of $A F B_{1}$ and $B_{2}$, respectively, and are produced in milkproducing animals [12], [13]. AFM in raw milk from cows and water buffaloes in Iran at 
high concentrations exceeding the maximum tolerance limit of the European Union/Codex Alimentarius Commission (50 ng/L) [13]. El-Nezami et al. [14] have reported on the presence of $\mathrm{AFM}_{1}$ in human breast milk from Victoria, Australia, and Thailand. AFM 1 was detected at high concentration putting infants at risk of contamination.

The ingestion of AFs from contaminated food has led to serious health complications in humans [15], [16], [17]. Therefore, different countries have implemented strict regulations for AFs in food and feed to maintain the health of individuals [18]. The safe limit of AFs lies in the range of $4-30 \mu \mathrm{g} / \mathrm{kg}$ for human consumption. The European Union has the strictest standard level with $\mathrm{AFB}_{1}$ and total AFs not beyond $2 \mu \mathrm{g} / \mathrm{kg}$ and $4 \mu \mathrm{g} / \mathrm{kg}$, respectively, in any product meant for direct consumption [19], [20]. Similarly, the maximum acceptable limit set for AFs in the United States is $20 \mu \mathrm{g} / \mathrm{kg}$ [21]. In Saudi Arabia suggests a ML of total AF $10-15 \mu \mathrm{g} / \mathrm{kg}$ depends on type of food [22]. Besides this, various innovative technologies and control strategies are applied for pre- and post-harvest management of AFs to enhance sustainable agricultural productivity [21].

Therefore, dry food should be routinely tested for the presence of AFs before entering the market. To this end, our study was designed to investigate the AFs contents of food commodities mostly consumed in Jeddah, Saudi Arabia.

\section{Material and Methods}

\section{Sample collection}

During the period July to December 2018, 34 different kinds of food commodities samples were collected randomly form Jeddah city, from different municipalities including: Alaziziya, Al Sharafiya, New Jeddah, Almatar, Aljamia, Albalad, Historical Jeddah, Aljanoob, Obhor, and Buriman. The total number of collected samples is 288 (258 dry foods and 30 dairy products) samples. With taking into consideration that most food commodities included in this study did not require additional processing as they were already "ready to eat." However, for not ready to eat food such as rice and spaghetti, samples were further processed using established cooking techniques to represent "ready to eat" foods.

\section{Samples collection technique}

\section{Dry food commodities}

- To achieve fairness of the food sample collection, samples were collected for same food's group/category such as brand, country of origin, canned and filled, furthermore: Samples collected from different markets and mixed well together to get a homogeneous sample

Samples were collected from 78 different markets and shops

200-300 g of each sample was collected

Each sample was collected in sterile plastic bag for specimen collecting

All dry food kept in a dry and cool area, temperature ranged $10-15^{\circ} \mathrm{C}$, to prevent spoilage and swelling until analyzing time

The most food commodities included in this study did not require additional

Processing as they were already "ready to eat."

\section{Dairy products}

- Commercial pasteurized, ultra-hightemperature processing milk, fresh milk, and cheese samples were collected in this study

- $\quad$ Milk samples purchased from supermarkets from different municipalities in Jeddah city

Different milk brands were collected including (Saudia, Alrabee, Almari, Alsafi, and Fresh milk)

Dairy products simples collected 1 or 2 days prior the analysis day, and kept in the refrigerator temperature of $2-4^{\circ} \mathrm{C}$

Samples were prepared in accordance with the Association of Official Analytical Chemists (AOAC) Official Method 49.3.07 for milk

\begin{tabular}{|c|c|}
\hline \multicolumn{2}{|c|}{ Food commodities categorized to following groups } \\
\hline Food category & \\
\hline \multirow[t]{3}{*}{ Bakery } & Bread (white, brown, and bran) \\
\hline & Toast white, *Tamis \\
\hline & *Samoli (white and brown), rusk (white and brown), cornflakes \\
\hline Cereal & Rice (white and brown), and spaghetti (white and brown), oats \\
\hline Legumes & Fava bean, lentil, and chickpeas \\
\hline Nuts & Walnut, cashew, peanut, pistachio, almond, hazelnut, and mix nuts \\
\hline Coffee & Arabic, and Turkish \\
\hline Dairy products & $\begin{array}{l}\text { Packed (milk, liquid yogurt, and yogurt), fresh milk, cheese (white, } \\
\text { and arish) }\end{array}$ \\
\hline
\end{tabular}

and milk products by AOAC Official Method $991.31[23]$.

\section{Determination of $A F M_{1}$ in milk products by high-performance liquid chromatography (HPLC) with using immunoaffinity column (IAC) for cleanup}

Standards of AFM solution $(0.5 \mu \mathrm{g} / \mathrm{mL})$ were supplied by Sigma/Aldrich Chemicals Co (St. Louis, USA). Acetonitrile (ACN), $n$ hexane and methanol, of HPLCgrade, were supplied by Sigma Chemical Company (St. Louis, MO, USA). Pure water was obtained from a Milli-Q purification system (Millipore, Bedford, MA, USA). IAC for AFM 1 (AflaM1) were purchased from VICAM (Milford, MA, USA). HPLC gradient grade methanol and 
ACN, and sodium chloride were purchased from Merck (Darmstadt, Germany). AflaTest-P IAC were purchased from VICAM (Milford, MA 01757, USA) for cleanup and isolation of AFs extracted from samples.

\section{AF standard}

The preparation of $\mathrm{AF}$ standard was carried out according to the AOAC [20]. Crystals of AFs $B_{1}, B_{2}$, $\mathrm{G}_{1}$, and $\mathrm{G}_{2}$ were diluted using benzene-ACN (98:2 v/v) to obtain a concentration of $8-10 \mu \mathrm{g} / \mathrm{ml}$ (stock solution).

\section{Extraction of $A F M_{1}$ by IAC}

Milk samples were analyzed for the presence of $\mathrm{AFM}_{1}$ using an IAC for cleanup and HPLC with fluorescence detection for determination based on the method of Dragacci et al. [24]. The milk samples (50 mL) were centrifuged at $2000 \times \mathrm{g}$ for $15 \mathrm{~min}$ and the upper fat layer was discarded. The skimmed milk was passed through an IAC (AflaM1) (VICAM) at a rate of about 1-2 drops/second. The column was washed with purified water $(10 \mathrm{~mL})$ to remove extraneous non-specific material. Following, the AFM eluted with $2.5 \mathrm{~mL}$ ACN-methanol (3:2; v/v). The eluate was evaporated to dryness using a stream of $\mathrm{N}_{2}$ for the determination of AFM1 by HPLC.

\section{Determination of AFM1 by HPLC}

\section{Derivatization}

The derivative of residue from above by adding $200 \mu \mathrm{L}$ hexane and $200 \mu \mathrm{L}$ trifluoroacetic acid to dry residue in vial. Shake on vortex mixer ca 5-10 s. Let mixture sit for $10 \mathrm{~min}$ at $40^{\circ} \mathrm{C}$, in heating block or bath; then evaporate to dryness under nitrogen on steam bath or heating block $\left(<50^{\circ} \mathrm{C}\right)$. Add $2 \mathrm{~mL}$ water-ACN $(75+25)$ to vial to dissolve residue and mix well using vortex mixer for LC analysis.

\section{- Determination of AFs in dry food \\ - Sample extraction.}

Twenty-five grams of finally ground sample were mixed with $5 \mathrm{~g}$ salt sodium chloride (NaCL) and place in blender jar. A $125 \mathrm{~mL}$ methanol:water (60:40) was added for extraction AFs from nuts, while in case of another samples were extracted using $200 \mathrm{ml}$ methanol:water (80:20). After covering the jar, blending was carried out at high speed for $1 \mathrm{~min}$. The extract was poured into fluted filter paper, and the filtrate was collected in a clean vessel.

\section{Extract dilution}

Pour $20 \mathrm{~mL}$ filtered extract into a clean vessel. Dilute extract with $20 \mathrm{~mL}$ of purified water and mix well. Filters dilute extract through glass microfiber filter into a clean vessel.

\section{Immunoaffinity chromatography}

Pass $10 \mathrm{~mL}$ filtered diluted extract $(10 \mathrm{~mL}=1 \mathrm{~g}$ sample equivalent) completely throughAflaTest-P affinity column (Vicam) at a rate of about 1-2 drops/second until air comes through column. Pass $10 \mathrm{~mL}$ of purified water through the column at a rate of about 2 drops/ second. Elute affinity column by passing $1.0 \mathrm{~mL} \mathrm{HPLC}$ grade methanol through column at a rate of 1-2 drops/ second and collecting all of the sample eluate $(1 \mathrm{~mL})$ in a glass vial. Evaporated to dryness using a stream of $\mathrm{N}_{2}$ to be determined using HPLC as following.

\section{Determination of AFs by HPLC}

\section{Derivatization}

The derivatives of samples and standard were done as follow $100 \mu \mathrm{l}$ of trifluoracetic acid (TFA) and were added to samples and mixed well for $30 \mathrm{~s}$ and the mixture stand for $15 \mathrm{~min}$. $900 \mu \mathrm{l}$ of water:ACN (9:1 v/v) were added and mixed well by vortex for $30 \mathrm{~s}$ and the mixture was used for HPLC analysis. In this step of reconstitution of the dry film, $A F B_{1}$ and $A F G_{1}$ were converted into other derivatives, $A F B_{2} a$ and $A F G_{2} a$, respectively, $\left(A F G_{1}\right.$ and $A F B_{1}$ ) had low fluorescence properties, therefore, and they were converted to $\mathrm{G}_{2}$ a and $\mathrm{B}_{2} \mathrm{a}$, which had high fluorescence properties, using (TFA).

\section{HPLC conditions}

HPLC (Agilent 1100 series) equipped with a fluorescence detector (G 1321A) analysis was carried out with a liquid chromatograph equipped with solvent delivery systems (Agilent Technologies, Inc. 200 Regency Forest Drive, Suite 330 Cary, NC 27511 USA) system containing a G1322A Vacuum Degasser, a G1312A binary pump and a reverse-phase analytical column packed with $\mathrm{C}_{18}$ material (Agilent ZORBAX, DB-5 $\mu \mathrm{m}, 150 \mathrm{~mm} \times 4.6 \mathrm{~mm}$ ). The mobile phase consisted of water:acetonitril:methanol (240:120:40), according by Deabes et al. [25], [26] Eshak et al. [27], El-Soud et al. [28], and Deabes et al. [29, ${ }_{a, b}$, for AFs $G_{1}, B_{1}, G_{2}$, and $B_{2}$, but for $M 1$ the isocratic system with water:methanol:ACN 66:17:17. Separation was performed at $40^{\circ} \mathrm{C}$ temperature at a flow rate of $1.0 \mathrm{ml} / \mathrm{min}$; the injection volume was $50 \mu \mathrm{l}$ for both standard solutions and sample extracts by autosampler (G1329A). The detection was performed using fluorescence detector and was operated at an excitation wavelength of $360 \mathrm{~nm}$ and an emission wavelength of $440 \mathrm{~nm}$. For AFM performed using fluorescence detector and was operated at an wavelength of $365 \mathrm{~nm}$ for excision and $435 \mathrm{~nm}$ for emission. AFs concentration in samples was determined from the standard curve, using peak area for quantitation AOAC [23].

The concentrations of $\mathrm{AFM}_{1}$ in milk were estimated from a standard curve $5.0-25 \mathrm{ng} / \mathrm{ml}$ methanol, 
prepared from $\mathrm{AFM}_{1}$ in chloroform $\mathrm{L}(9.93 \mathrm{mg} / \mathrm{ml})$. An $A F M_{1}$ standard as injected every ten injections as a quality control. AFM was stored at $-20^{\circ} \mathrm{C}$ in a sylilated vial wrapped in aluminum foil. Since AFs $B_{1}, B_{2} G_{1}$, $G_{2}$, and $M_{1}$ are a carcinogen, care was exercised to avoid personal exposure and proper decontamination procedures with $10 \%$ sodium hypochlorite were used.

\section{Validation method}

\section{Accuracy}

The accuracy of the method was studied by recovery studies. The accuracy of the method was determined by percentage recovery of AFs in the spiked sample at three concentration levels. The resultant samples were then analyzed (replicated 3 times) and the average percentage recoveries were calculated as:

$$
\begin{gathered}
\text { Actual amount of AFs } \\
\text { Recovery }(\%)=\frac{(\mathrm{ng} / \mathrm{g}) \text { quantity }}{\text { Initial amount of AFs }} \times 100 \\
(\mathrm{ng} / \mathrm{g}) \text { were added }
\end{gathered}
$$

The samples were examined by HPLC after extraction according to AOAC method 991.31 [23]. The averages of 20 analysis results and their standard deviations and limit of detection (LOD) and limits of quantitation (LOQ) values were obtained according to Eqs. (1) and (2) for each experiment by analyzing three samples with two injections at a time in the HPLC under the chromatographic conditions mentioned above by the ICH guidelines (ICH Q2(R1), [30] and NATA Technical Note 17 [31].

\section{LOD}

The lowest concentration of working solution of the analyst was further diluted with (ACN:water 1:9, v/v) to yield a series of appropriate concentrations. LOD of the method was determined by injecting progressively low concentrations of the standard solutions and $\mathrm{S} / \mathrm{N}$ ratio for each concentration was observed. The concentration having signal-to-noise ratio nearly three has been found as LOD.

\section{LOQ}

The lowest concentration of working solution of the analyst was further diluted with ACN:water 1:9, $\mathrm{v} / \mathrm{v}$ to yield a series of appropriate concentrations. $L O Q$ of the developed method was determined by injecting progressively low concentrations of the standard solutions and observed $\mathrm{S} / \mathrm{N}$ ratio (signal-to-noise ratio) of each concentration. The $L O Q$ for investigated compound was established at signal-to-noise ratio approaching nearly to 10 .
LOD is expressed as the analyst concentration corresponding to:

$$
\begin{aligned}
& \text { a. Mean value of the blank sample }+3 \mathrm{~s} \\
& \text { b. } 0+3 \mathrm{~s} \text { or the mean value of the blank } \\
& \text { sample }+4.65 \mathrm{~s} . \\
& \mathrm{LOQ}=10 \mathrm{~s}+\mathrm{X}
\end{aligned}
$$

where:

$\mathrm{s}=$ standard deviation for the blank or blank fortified with an analyst samples

$X=$ measured value

\section{Statistical analysis}

Descriptive statistics were calculated of the studied groups. Therefore, a Mann-Whitney U-test was used to determine the significance of the difference. A Kruskal-Wallis test was used to test the significance of the differences among the three samples levels, where a value of $\alpha=0.05$ was considered to indicate statistical significance.29 SPSS, version 22 (IBM Corp., Armonk, NY, USA) was used for the statistical analysis according to IBM Corp. [32].

\section{Results}

In the present study, a total of 288 (258 dry foods and 30 dairy products) samples were detect AFs $\left(B_{1}, B_{2}, G_{1}\right.$, and $\left.G_{2}\right)$ and $M_{1}$ in dairy products by HPLC.

A review of monitoring studies on the occurrence of AFs in food products has demonstrated that AFs are still being found frequently in food products at levels that are of significant concern for consumer protection [33], [34].

It is worthy to mention that the current investigation was carried out to determined the AFs (AFB1, AFB2, AFG1, AFG2) contamination levels in samples (Human Food Commodities) were obtained from Jeddah, markets. Then, the obtained data are recorded in Tables 1 and 2 .

The obtained results of Tables 1 and 2 indicated that the $\%$ of incidence $7 \%$ in cereals samples. The concentrations of $A F s\left(A F B_{1}, A F B_{2}, A F G_{1}\right.$, and $A F G_{2}$ ) ranged from $0.46-5.83,0.0-0.0,0.67-1016$, to $0.0-$ $0.0 \mu \mathrm{g} / \mathrm{kg}$ in the cereals samples collected from Jeddah, respectively.

The obtained results of Table 1 indicated that the incidence rat $\%$ of bakery $0 \%$ and legumes but in coffee $62 \%$, cereals $7 \%$, nuts 27.3 , and dairy products $13.3 \%$ for $A F s\left(A F B_{1}, A F B_{2}, A F G_{1}\right.$, and $\left.A F G_{2}\right)$ in samples collected from Jeddah region, respectively. The highly percentage of AFs was found in nuts. The results indicated that the incidence rate $27.3 \%$ of nut 
Table 1: Distribution of food groups commodities obtained from Jeddah markets for aflatoxin contamination $\mu \mathrm{g} / \mathrm{kg}$

\begin{tabular}{|c|c|c|c|c|c|c|c|c|c|c|c|}
\hline \multirow[t]{2}{*}{ Food groups } & \multirow[t]{2}{*}{ AFs } & \multirow[t]{2}{*}{ Incidence rate $(\%)$} & \multicolumn{6}{|c|}{ AFs concentrations $\mu \mathrm{g} / \mathrm{kg}$} & \multicolumn{3}{|c|}{ Percentiles } \\
\hline & & & Min. & Max. & Mean & $\pm S D$ & Median & IQR & 10 & 90 & 95 \\
\hline \multirow[t]{5}{*}{ Bakery bread (white, brown, and bran) } & \multirow{5}{*}{$\begin{array}{l}\mathrm{AFB}_{1} \\
\mathrm{AFB}_{2} \\
\mathrm{AFG}_{1} \\
\mathrm{AFG} \\
\mathrm{TAF}\end{array}$} & $0 / 51(0 \%)$ & - & - & - & - & - & - & - & - & - \\
\hline & & & - & - & - & - & - & - & - & - & - \\
\hline & & & - & - & - & - & - & - & - & - & - \\
\hline & & & - & - & - & - & - & - & - & - & - \\
\hline & & & - & - & - & - & - & - & - & - & - \\
\hline \multirow{5}{*}{$\begin{array}{l}\text { Cereals rice (white and brown), spaghetti (white and } \\
\text { brown), oats }\end{array}$} & \multirow{5}{*}{$\begin{array}{l}\mathrm{AFB}_{1} \\
\mathrm{AFB}_{2} \\
\mathrm{AFG}_{1} \\
\mathrm{AFG} \\
\mathrm{TAF}\end{array}$} & $5 / 72(7 \%)$ & 0.46 & 5.38 & 0.160 & 0.79 & 0.000 & 0.00 & 0.0 & 0.00 & 1.03 \\
\hline & & & - & - & - & - & - & - & - & - & - \\
\hline & & & 0.67 & 1.16 & 0.025 & 0.16 & 0.000 & 0.00 & 0.0 & 0.00 & 0.0 \\
\hline & & & - & - & - & - & - & - & - & - & - \\
\hline & & & 0.46 & 5.38 & 0.186 & 0.89 & 0.000 & 0.00 & 0.0 & 0.00 & 1.26 \\
\hline \multirow[t]{5}{*}{ Legumes bread (white, brown, and bran) } & \multirow{5}{*}{$\begin{array}{l}\mathrm{AFB}_{1} \\
\mathrm{AFB}_{2} \\
\mathrm{AFG}_{1} \\
\mathrm{AFG} \\
\mathrm{TAF}\end{array}$} & 0/28 (0\%) & - & - & - & - & - & - & - & - & - \\
\hline & & & - & - & - & - & - & - & - & - & - \\
\hline & & & - & - & - & - & - & - & - & - & - \\
\hline & & & - & - & - & - & - & - & - & - & - \\
\hline & & & - & - & - & - & - & - & - & - & - \\
\hline \multirow[t]{5}{*}{ Coffee Arabic Turkish } & \multirow{5}{*}{$\begin{array}{l}\mathrm{AFB}_{1} \\
\mathrm{AFB}_{2} \\
\mathrm{AFG}_{1} \\
\mathrm{AFG}_{2} \\
\mathrm{TAF}\end{array}$} & $5 / 8(62.5 \%)$ & 0.29 & 0.93 & 0.37 & 0.36 & 0.372 & 0.71 & 0.0 & - & - \\
\hline & & & - & - & - & - & - & - & - & - & - \\
\hline & & & - & - & - & - & - & - & - & - & - \\
\hline & & & - & - & - & - & - & - & - & - & - \\
\hline & & & 0.29 & 0.93 & 0.37 & 0.36 & 0.372 & 0.71 & 0.0 & - & - \\
\hline \multirow{5}{*}{$\begin{array}{l}\text { (Nuts) walnut cashew peanut pistachio almond } \\
\text { hazelnut }\end{array}$} & \multirow{5}{*}{$\begin{array}{l}\mathrm{AFB}_{1} \\
\mathrm{AFB}_{2} \\
\mathrm{AFG}_{1} \\
\mathrm{AFG}_{2} \\
\mathrm{TAF}\end{array}$} & $27 / 99$ (27.3\%) & 0.19 & 482.4 & 11.14 & 60.5 & 0.000 & 0.036 & 0.0 & 2.66 & 12.3 \\
\hline & & & 0.09 & 3.34 & 0.11 & 0.41 & 0.000 & 0.00 & 0.0 & 0.29 & 0.78 \\
\hline & & & 0.19 & 87.1 & 2.11 & 11.6 & 0.000 & 0.00 & 0.0 & 0.47 & 1.88 \\
\hline & & & 0.09 & 45.4 & 1.24 & 6.45 & 0.000 & 0.00 & 0.0 & 0.14 & 0.87 \\
\hline & & & 0.09 & 579.4 & 14.7 & 76.7 & 0.000 & 0.19 & 0.0 & 4.53 & 12.7 \\
\hline \multirow{2}{*}{$\begin{array}{l}\text { Dairy products milk, liquid yogurt, yogurt), fresh milk, } \\
\text { cheese (white, arish) }\end{array}$} & \multirow[t]{2}{*}{$\mathrm{AFM}_{1}$} & \multirow{2}{*}{$4 / 30(13.3)$} & $\mu \mathrm{g} / \mathrm{ml}$ & & & & & & 0.1 & 0.07 & 0.1 \\
\hline & & & 0.06 & 0.1 & 0.061 & 0.01 & 0.06 & 0.00 & & & \\
\hline
\end{tabular}

Min: Minimum, Max: Maximum, SD: Standard division, IQR: Interquartile range.

Table 2: Aflatoxin detection range in dry food commodities

\begin{tabular}{|c|c|c|c|c|c|c|c|c|c|c|}
\hline \multirow[t]{3}{*}{ Aflatoxins $\mu \mathrm{g} / \mathrm{kg}$} & \multicolumn{10}{|c|}{ Incidence rate (\%) } \\
\hline & \multicolumn{2}{|c|}{$\mathrm{AFB}_{1}$} & \multicolumn{2}{|c|}{$\mathrm{AFB}_{2}$} & \multicolumn{2}{|c|}{$\mathrm{AFG}_{1}$} & \multicolumn{2}{|c|}{$\mathrm{AFG}_{2}$} & \multicolumn{2}{|c|}{ TAFs } \\
\hline & $\mathrm{n}$ & $\%$ & $\mathrm{n}$ & $\%$ & $n$ & $\%$ & $\mathrm{n}$ & $\%$ & $\mathrm{n}$ & $\%$ \\
\hline$<$ LOD & 222 & 86.0 & 242 & 93.8 & 240 & 93.0 & 246 & 95.3 & 221 & 85.7 \\
\hline LOD $<-<2$ & 21 & 8.1 & 15 & 5.8 & 14 & 5.4 & 8 & 3.1 & 20 & 7.75 \\
\hline $2<-<4$ & 7 & 2.7 & 1 & 0.4 & 0 & 0.0 & 0 & 0.0 & 4 & 1.55 \\
\hline $4<-<20$ & 4 & 1.6 & 0 & 0.0 & 0 & 0.0 & 1 & 0.4 & 9 & 3.5 \\
\hline$>20$ & 4 & 1.6 & 0 & 0.0 & 4 & 1.6 & 3 & 1.2 & 4 & 1.55 \\
\hline Total & 258 & 100.0 & 258 & 100.0 & 258 & 100.0 & 258 & 100.0 & 258 & 100.0 \\
\hline
\end{tabular}

samples collected from Jeddah, was contaminated with AFs $B_{1}$ and $B_{2}$, while $20 \%$ from were contaminated with $A F s G_{1}$ and $G_{2}$. The concentrations of $A F s\left(A F B_{1}, A_{F B}\right.$, $A F G_{1}$, and $A F G_{2}$ ) were ranged from 0.19-482.4, 0.09$3.34,0.19-87.1$, to $0.09-579 \mu \mathrm{g} / \mathrm{kg}$ in the nut samples collected from Jeddah markets.

Figure $1 \mathrm{a}$ and $\mathrm{b}$ shows the HPLC chromatogram of $A F s\left(A F G_{1}, A F B_{1}, A F G_{2}\right.$, and $\left.A F B_{2}\right)$ separation of standards and high concentration of $A F s$ in walnut. The highly percentage of AFs was found in walnuts, with risk levels $100 \%$ with a concentrations of $\mathrm{AFs}\left(\mathrm{AFB}_{1}\right.$, $A F B_{2}, A F G_{1}$, and $A F G_{2}$ ) ranged from 84.447-482.380, $0.052-3.337,20.008-87.142$, to $12.732-45.40 " \mathrm{\mu g} / \mathrm{kg} "$ while in Pistachio $(0.716-4.865,0.01 .744,0.0-0.296$, and $0.0-0.871 \mathrm{Mg} / \mathrm{kg}, "$ respectively).

In a survey study of peanut products in North America, $19 \%$ of 1416 samples examined were contaminated with an average level of $1 \mu \mathrm{g} / \mathrm{kg} \mathrm{AFB}{ }_{1}$ [35]. In Thailand, $49 \%$ of 216 samples contained AFB at an average level of $424 \mu \mathrm{g} / \mathrm{kg}$ [36]. In parts of India, $100 \%$ of maize samples have been found contaminated with $A F$ in the range of $6250-15600 \mu \mathrm{g} / \mathrm{kg}$ [37].

The results in Table 2 illustrated that the rat of incidence of contaminated samples $86.0 \%, 93.8,93.0$, and 95.3 in $<$ LOD in the total of 222 samples for AFs $B_{1}$ and $B_{2}, G_{1}$ and $G_{2}$, respectively, while with $L O D<-<2$ in the total of 21 samples for $A F s B_{1}$ and $B_{2}, G_{1}$ and $\mathrm{G}_{2}$ found that incidence \% of contaminated samples $8.1,5.8,5.4$, and 3.1 , respectively. The total of AFs concentration $\mu \mathrm{g} / \mathrm{kg} \mathrm{B} \mathrm{B}_{1}, \mathrm{~B}_{2} \mathrm{G}_{1}$, and $\mathrm{G}_{2}$ was contaminated in dry food samples $(n=258)$ incidence rat of $100 \%$.

The obtained data (Tables 3 and 4 and Figure 2a-e) illustrated that the mean recovery percentages of all tested AFs (AFB, $A F B_{2}, A F G_{1}$, and $A F G_{2}$ ) extracted by the first former method from spiked samples.

The average recoveries of AFs spiked on levels $(5 \mu \mathrm{g} / \mathrm{kg})$ in peanut were $79.0 \%$ for $\mathrm{AFB}_{1} ; 76.5 \%$ for $A F B_{2} ; 83.7 \%$ for $A F G_{1}$, and $67.2 \%$ for $A F G_{2}$ and $M_{1} 89.73$.

\section{Discussion}

AFs are hepatocarcinogens and have been classified as Class 1 human carcinogen [3]. The average daily intake of $\mathrm{AFB}_{1}$ in the high-risk area was $184.1 \mu \mathrm{g}$. hepatitis B can act synergistically with AFs to increase the risk of hepatocellular carcinoma [38]. According to the World Health Organization, chronic hepatitis $B$ virus infection occurs more frequently (high infection $>8 \%$ ) in developing world including Asia and the Pacific Basin (excluding Japan, Australia, and New Zealand), sub-Sahara Africa, the Amazon Basin, parts of the Middle East, the Central Asian Republics, and some countries in Eastern Europe, while the rest of Europe infection rates are below $1 \%$ and less than 


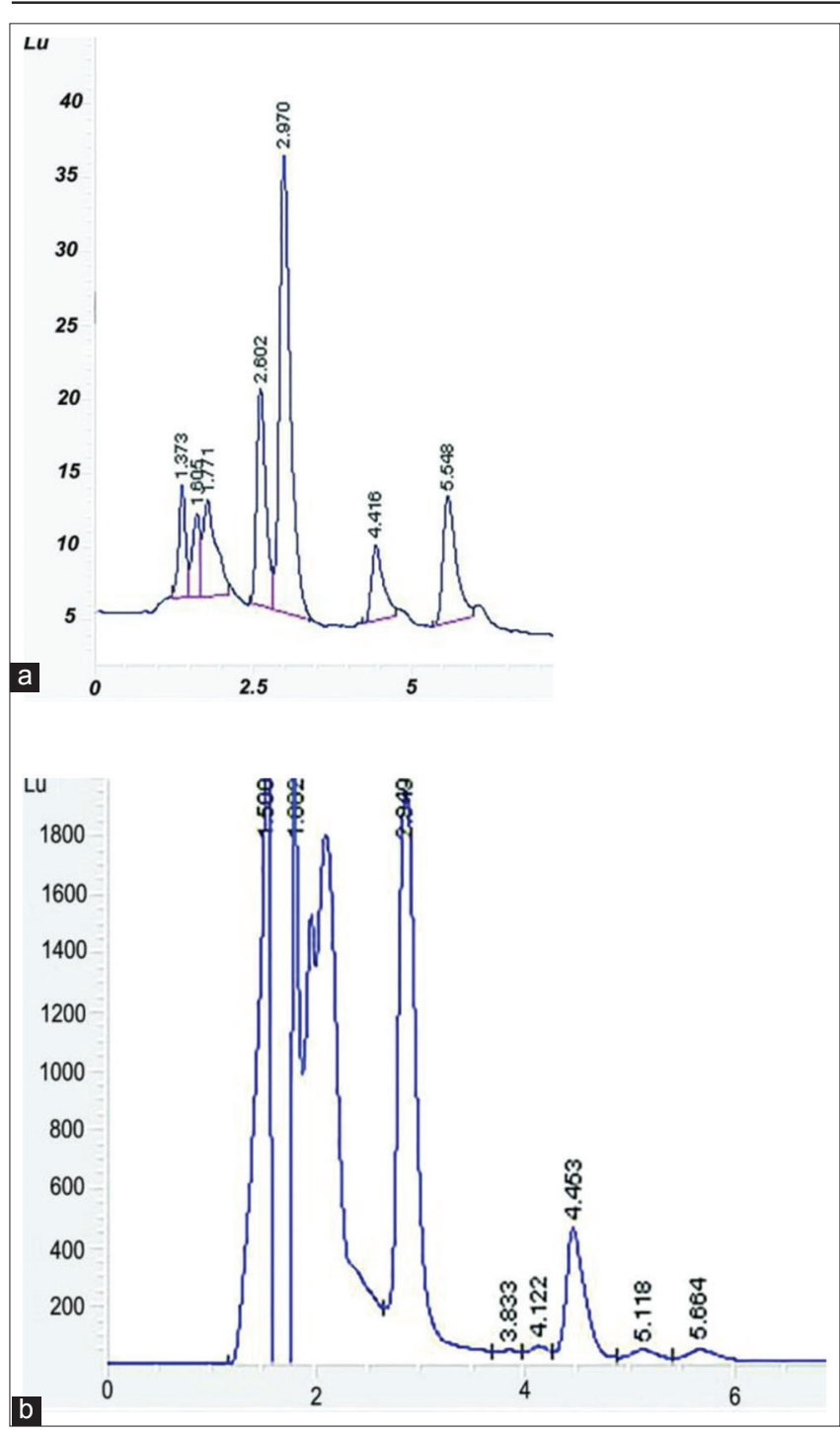

Figure 1: High-performance liquid chromatography chromatograms (a) standard of aflatoxins (AFs), (b) nut sample +AFs. R.T: Retention time: $A F G_{1}(2.4), A F B_{1}(2.9), A F G_{2}(4.4), A F B_{2}(5.5)$

$20 \%$ of the population is ever exposed to hepatitis $B$ virus infection [39]. Overall, epidemiological studies of human populations exposed to diets naturally contaminated with AFs revealed an association between the high incidence of liver cancer in Africa and elsewhere and dietary intake of AFs [40].

Table 3: Recovery rate of validated HPLC method for aflatoxins in food matrices

\begin{tabular}{lllll}
\hline No. of replicated samples & $\mathrm{AFG}_{1}$ & $\mathrm{AFB}_{1}$ & $\mathrm{AFG}_{2}$ & $\mathrm{AFB}_{2}$ \\
\hline 1 & 79.0 & 95.22 & 53.25 & 63.1 \\
2 & 78.4 & 87.28 & 53.25 & 72.6 \\
3 & 78.0 & 89.66 & 60.0 & 65.13 \\
Mean & 78.46 & 90.72 & 55.5 & 66.49 \\
\hline AFG $_{1}$ : Aflatoxin $\mathrm{G}_{1}, \mathrm{AFB}_{1}$ : Aflatoxin $\mathrm{B}_{1}, \mathrm{AFG}_{2}:$ Aflatoxin $\mathrm{G}_{2}, \mathrm{AFB}_{2}:$ Aflatoxin $\mathrm{B}_{2} \mathrm{AFM}_{1}:$ Aflatoxin $\mathrm{M}_{1}$.
\end{tabular}

Often up to 1 in 10 of the population in subSaharan Africa are infected with hepatitis B and C, $\mathrm{AF}$ intake raise the risk of liver cancer by more than ten-fold compared to the exposure of both hepatitis alone [41].

Table 4: Recovery rate of validated HPLC method for aflatoxins $M_{1}$ in fluid milk

\begin{tabular}{lll}
\hline Sample & Spike level $(\mathrm{ng} / \mathrm{mL})$ & Recovery $(\%)$ \\
\hline Fluid milk & 5 & 89.73 \\
\hline
\end{tabular}

In our results found that in walnuts AFB1 exceed in the average daily intake of $A F B$, the high-risk more than $184.1 \mu \mathrm{g}$ set by Turner et al. [38], it is average $271.70 \mu \mathrm{g}$. The obtained results of Tables 5 illustrated the incidence rat $\%$ were contaminated with AFs $B_{1}$ and $G_{1}$. The detection range in dry food commodities sample was contaminated with AFs ranged from 0.036 to 482.4 for $A F B_{1}$ and $A F G_{1} 0.035-87.1 \mu \mathrm{g} / \mathrm{kg}$ when the samples $(n=258)$ were analyzed the positive samples 36 and 18 for $A F s, B_{1}$ and $G_{1}$ contained the incidence rat $\% 14.34$ and $7 \%$, respectively.

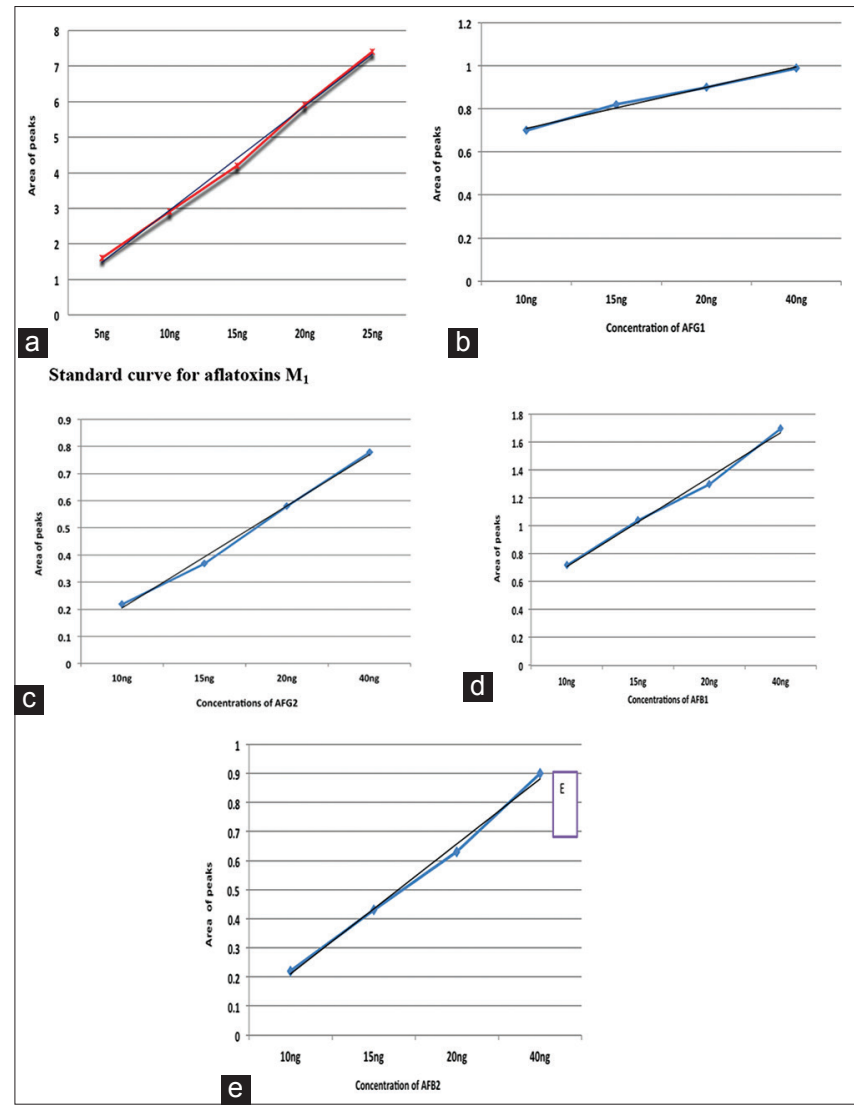

Figure 2: Calibration curves of $F M_{1}(a) ; A F G_{1}(b) ; A F B_{1}(c) ; A F G_{1}(d)$; $A F B_{2}(e)$. AF: Aflatoxin

A review of monitoring studies on the occurrence of AF in food products has demonstrated that AFs are still being found frequently in food products at levels that are of significant concern for consumer protection [33], [34]. The occurrence of AFs in dried fruits and nuts was surveyed in the study by Luttfullah and Hussain, [42] in Pakistan. They found the percentage of contamination for total AFs in the samples such as in dried apricot $(20 \%)$, dates (10\%), dried figs (50\%), dried mulberries $(26 \%)$, and raisins $(20 \%)$, while in apricot kernels (26\%), almonds without shell $(30 \%)$, walnuts with shell $(40 \%)$, walnuts without shell $(70 \%)$, peanut with shell $(40 \%)$, peanuts without shell $(50 \%)$, pistachios with shell $(20 \%)$, pistachios without shell $(50 \%)$, and pine nuts with shell $(20 \%)$. The highest contamination levels of AFs were found in one peanut sample (14.5 $\mathrm{mg} / \mathrm{kg})$ and one pistachio sample (14 mg/kg). Molds of the genus Aspergillus frequently decay the kernel of pistachio nuts [43]. On the other 
Table 5: Aflatoxins detection range in dry food commodities

\begin{tabular}{|c|c|c|c|c|c|c|c|c|c|}
\hline \multirow[t]{3}{*}{$\overline{\mathrm{AFs}}$} & \multicolumn{9}{|c|}{ Aflatoxin contamination $\left(\mathrm{Ve}^{+}\right) \mu \mathrm{g} / \mathrm{kg}$} \\
\hline & \multirow[t]{2}{*}{ Incidence rate (\%) } & \multirow[t]{2}{*}{ Mean \pm SD } & \multirow[t]{2}{*}{ Min. } & \multirow[t]{2}{*}{ Max. } & \multicolumn{5}{|c|}{ Detection rang } \\
\hline & & & & & $\mathrm{AF}<2(\%)$ & $\mathrm{AF}>2(\%)$ & $\mathrm{AF}>4(\%)$ & $\mathrm{AF}>10(\%)$ & $A F>20(\%)$ \\
\hline $\mathrm{AFB}_{1}$ & $36 / 258(14.34)$ & $4.3 \pm 37.7$ & 0.036 & 482.4 & $21(58.3)$ & $15(41.6)$ & $8(22.2)$ & $6(16.6)$ & $4(11.1)$ \\
\hline $\mathrm{AFG}_{1}$ & $18 / 258(7)$ & $0.82 \pm 7.2$ & 0.035 & 87.1 & $14(77.7)$ & $4(22.4)$ & $4(22.4)$ & $4(22.4)$ & $4(22.4)$ \\
\hline TAF & $37 / 258(14.34)$ & $5.8 \pm 47.9$ & 0.045 & 579.4 & $20(54.1)$ & $17(45.9)$ & $13(35.1)$ & $6(16.2)$ & $4(10.8)$ \\
\hline
\end{tabular}

Table 6: LOD and LOQ values of validated HPLC method for aflatoxins

\begin{tabular}{llll}
\hline Found concentrations & $\begin{array}{l}\mathrm{AFG}_{1} \text { Initial concentration } \\
\text { was added }(5 \mathrm{ng} / \mathrm{g})\end{array}$ & $\begin{array}{l}\mathrm{AFB}_{1} \text { Initial concentration } \\
\text { was added }(45 \mathrm{ng} / \mathrm{g})\end{array}$ & $\begin{array}{l}\mathrm{AFG}_{2} \text { Initial concentration } \\
\text { was added }(5 \mathrm{ng} / \mathrm{g})\end{array}$ \\
\hline Actual amount (quantity) & 3.95 & 42.85 & 2.13 \\
Actual amount (quantity) & 3.92 & 39.28 & 2.13 \\
added $(15 \mathrm{ng} / \mathrm{g})$ & 9.47 \\
Actual amount (quantity) & 3.9 & 40.35 & 2.4 \\
Mean & $3.9 \pm 0.02$ & $40.83 \pm 1.8$ & $2.22 \pm 0.15$ \\
\hline
\end{tabular}

Mean $\pm S D(n=3)$, SD: Standard division.

hand, pistachio nuts are among the commodities with the highest risk of AF contamination [44].

Table 7: Limit of detection and limit of quantitation values of validated HPLC method for aflatoxins in peanut

\begin{tabular}{llllll}
\hline Validation paramter & $\mathrm{AFG}_{1}$ & $\mathrm{AFB}_{1}$ & $\mathrm{AFG}_{2}$ & $\mathrm{AFB}_{2}$ & $\mathrm{AFM}_{1}$ \\
\hline LOD & 0.05 & 0.03 & 0.02 & 0.07 & 0.06 \\
LOQ & 0.4 & 0.3 & 0.2 & 0.2 & 0.42 \\
\hline
\end{tabular}

0.2

$\mathrm{G}_{2}, \mathrm{AFB}_{2}$ : Aflatoxin $\mathrm{B}_{2}, \mathrm{AFM}_{1}$ : Aflatoxin $\mathrm{M}_{1}$.

AF contamination in some edible dry fruits and nuts has been reported by Abdel-Hafez and Saber [45] and Singh et al. [46]. AFs were detected in $90 \%$ of hazelnut samples $(25-175 \mathrm{mg} / \mathrm{kg})$ and $75 \%$ of walnut samples $(15-25 \mathrm{mg} / \mathrm{kg})$. In a survey of peanut products in North America, $19 \%$ of 1416 samples examined were contaminated with an average level of $1 \mu \mathrm{g} / \mathrm{kg}$ [35] in Thailand, $49 \%$ of 216 samples contained AFB at an average level of $424 \mu \mathrm{g} / \mathrm{kg}$ [36]. AFs are present in food chain consumption of $\mathrm{AF}$ in many parts of the world varies from 0 to $30,000 \mathrm{ng} / \mathrm{kg} /$ day [47]. Some factors such as high temperature and low moisture can result in cracks in the seed and subsequent invasion by the fungus. Temperature and moisture are the dominant factors that affect AF contamination of corn. Environmental conditions most favorable for maximum growth and $\mathrm{AF}$ production by $A$. flavus are temperatures $>30^{\circ} \mathrm{C}$, maximum relative humidity of $>85 \%$, and water activity of $0.98-0.99$ [48]. Thus, A. flavus can infect with proper moisture/ temperature conditions during storage almost any stored product [49]. AF formation in groundnut is favored by prolonged end of season drought and associated elevated temperature [50]. Cereals and cereal-based products are the major foods for human consumption worldwide [51]. Among cereals, rice and corn are mostly contaminated by AFs in natural conditions due to changes in agricultural practices. The occurrence of AFs is common in wide varieties of food include peanuts, nuts, figs, corn, rice, spices, and dried fruits [52]. It has been shown that among the tested cereals, $37.6 \%$ were at least contaminated by any of the AFs [53]. Although rice is not the high-risk commodity for AFs contamination, AFB besides other mycotoxins have been found in rice from China, Egypt, India, Iran, Malaysia, Nepal, Pakistan, the Philippines, United Kingdom, and the United States [42], [54]. Palumbo et al. [55] found that AFs in rice of the highest mean concentrations of AFB1 $n=124$; mean
3.1-3.3 $\mu \mathrm{g} / \mathrm{kg}$; max: $91.7 \mu \mathrm{g} / \mathrm{kg}$. In our results, the total AFs were detected in some foods above the acceptable limits set by the European Union $4 \mathrm{ug} / \mathrm{kg}$ could be attributed to some suitable factors such as $\mathrm{pH}$, nutrient composition, moisture content water activity, as well as external factors as temperature, relative humidity, soil properties, insects, and rodents attack [56], [57]. Atanda et al. [56] also suggested that these factors, however, do not work in solitude. Therefore, two or more factors may have to be met before fungal growth and corresponding toxin production can be effected.

Fungal infestation, growth, and $\mathrm{AF}$ development are linked principally to water activity (Aw). This observation is attributable to incorrect drying which display stored cereals and legumes to growth of mycotoxigenic fungi such as Aspergillus species which is conjectured to also increase with storage time [51], [58], [59].

\section{Validation}

The calibration curves, in the ranged of 5-25 ng/mL for $\mathrm{AFM}_{1}$ and $5-40 \mathrm{ng} / \mathrm{ml}$ for $\left(\mathrm{AFB}_{1}, \mathrm{AFB}_{2}\right.$, $A F G_{1}$, and $A F G_{2}$ ), were linear in the studied working.

The good accuracy and precision results are obtained in Tables 4, 6 and 7. The LOD was calculated by the $\mathrm{ICH}$ guidelines [30] for those concentrations that provide a signal-to-noise ratio of 3:1. The obtained $\mathrm{LOD}$ values for $A F B_{1}, A F B_{2}, A F G_{1}$, and $A F G_{2}$ were below $0.1 \mu \mathrm{g} / \mathrm{kg}\left(\mathrm{AG}_{2}\right.$ and $A G_{1} 0.04 \mu \mathrm{g} / \mathrm{kg}$; and $A B_{1}$ and $\mathrm{AB}_{2} 0.02 \mu \mathrm{g} / \mathrm{kg}$ ). The LOQs were set and experimentally confirmed at level of $1 \mu \mathrm{g} / \mathrm{kg}$. These limits are well below established by the Codex MLs for food commodities.

\section{Conclusion}

This study shows that the incidence of AFs contamination in food commodities are consuming in Jeddah. The results demonstrate the importance of routine monitoring of AFs contamination in various food commodities should be performed regularly and the 
nuts contained high levels of AFs. The legal regulations must be unauthorized for human consumption to control the health risks associated from AFs. Good processing, handling, transportation, storage system, and the source of production to imported for local market in Saudi Arabia can reduce the exposure to AFs.

\section{Acknowledgments}

All authors are highly grateful to the authority of the respective King Abdulaziz University, Jeddah, Saudi Arabia, for their support in doing this research would like to express Food Nutrition Department, Faculty of Home Economics, King Abdulaziz University, Jeddah, Saudi Arabia. A Project Funded 1-18-04-009-0007 we would like to thank for their financial support.

\section{References}

1. Wilson DM, Mubatanhema W, Jurjevic Z. Biology and ecology of mycotoxigenic Aspergillus species as related to economic and health concerns. Adv Exp Med Biol. 2002;504:3-17. https://doi. org/10.1007/978-1-4615-0629-4_2

PMid:11922097

2. Bathnagar D, Garcia S. Aspergillus. In: Labbe RG, Garcla S, editors. Guide to Foodborne Pathogens. New York: John Wiley and Sons; 2001. p. 35-49.

3. International Agency for Research on Cancer. Some Naturally Occurring Substances: Food Items and Constituents, Heterocyclic Amines and Mycotoxins. IARC Monographs on Evaluation of Carcinogenic Risk to Humans. Lyon, France: International Agency for Research on Cancer; 1993. p. 56. https://doi.org/10.1016/0003-2670(94)80328-5

4. Theumer MG, Henneb Y, Khoury L, Snini SP, Tadrist S, Canlet C et al. Genotoxicity of aflatoxins and their precursors in human cells. Toxicol Lett. 2018;287:100-7. https://doi.org/10.1016/j. toxlet.2018.02.007

PMid:29421331

5. IARC. Aflatoxins, IARC Monographs on the Evaluvation of Carcinogenic Risks on Humans. Mono100-23. Lyon, France: IARC; 2012. Available from:https://monographs.iarc.fr/ENG/ Monographs/\%E2\%80\%A6/mono100F-23.pdf.

6. Joint $\mathrm{FAO} / \mathrm{WHO}$ Expert Committee on Food Additives. $49^{\text {th }}$ Meeting of the Joint FAO/WHO Expert Committee on Food Additives. In: Safety Evaluation of Certain Food Additives and Contaminants: Aflatoxins WHO Food Additives Series No. 40. Geneva: World Health Organization; 1998. p. 359-469. https:// doi.org/10.1191/096032799678839888

7. Thuvander A, Moller T, Barbieri HE, Jansson A, Salomonsson AC, Olsen M. Dietary intake of some important mycotoxins by the Swedish population. Food Addit Contam. 2001;18(8):696-706. https://doi.org/10.1080/02652030121353 PMid:11469326

8. Ministry of Agriculture and Rural Affairs, Republic of Turkey. Data on Aflatoxins in Hazelnuts, Pistachios, Walnuts and Almonds during 1998-2002. Beijing, China: Ministry of Agriculture and
Rural Affairs; 2002.

9. Ito Y, Peterson SW, Wicklow DT, Goto T. Aspergillus pseudotamariia new aflatoxin producing species in Aspergillus section Flavi. Mycol Res. 2001;105:233-9. https://doi.org/10.1017/ s0953756200003385

10. Peterson SW, Ito Y, Horn BW, Goto T. Aspergillus bombycis, a new aflatoxigenic species, $A$. nomius. Mycologia. 2001;93:689703. https://doi.org/10.1080/00275514.2001.12063200

11. Ehrlich KC, Chang PK, Yu J, Cotty PJ. Aflatoxins biosynthesis cluster gene cypA is required for $G$ aflatoxin formation. Appl Environ Microbiol. 2004;70:6518-24. https://doi.org/10.1128/ aem.70.11.6518-6524.2004 PMid: 15528514

12. Lanyasunya TP, Wamae LW, Musa HH, Olowofeso O, Lokwaleput IK. The risk of mycotoxins contamination of dairy feed and milk on smallholder dairy farms in Kenya. Pak J Nutr. 2005;4(3):162-9.

13. Rahimi E, Bonyadian M, Rafei M, Kazemeini HR. Occurrence of aflatoxin $\mathrm{M} 1$ in raw milk of five dairy species in Ahvaz, Iran. Food Chem Toxicol. 2010;48(1):129-31. https://doi.org/10.1016/j. fct.2009.09.028 PMid:19786054

14. El-Nezami HS, Nicoletti G, Neal GE, Donohue DC, Ahokas JT. Aflatoxin M1 in human breast milk samples from Victoria, Australia and Thailand. Food Chem Toxicol. 1995;33(3):173-9. https://doi.org/10.1016/0278-6915(94)00130-g PMid:7896226

15. Fung F, Clark RF. Health effects of mycotoxins: A toxicological overview. J Toxicol Clin Toxicol. 2004;42(2):217-34. PMid: 15214629

16. Binder EM, Tan LM, Chin LJ, Handl J, Richard J. Worldwide occurrence of mycotoxins in commodities, feeds and feed ingredients. Anim Feed Sci Technol. 2007;137:265-82. https:// doi.org/10.1016/j.anifeedsci.2007.06.005

17. Sherif SO, Salama EE, Abdel-Wahhab MA. Mycotoxins and child health: The need for health risk assessment. Int $\mathrm{J}$ Hyg Environ Health. 2009;212(4):347-68. https://doi.org/10.1016/j. ijheh.2008.08.002

PMid: 18805056

18. Juan C, Ritieni A, Mañes J. Determination of trichothecenes and zearalenones in grain cereal, flour and bread by liquid chromatography tandem mass spectrometry. Food Chem. 2012;134(4):2389-97. https://doi.org/10.1016/j. foodchem.2012.04.051

PMid:23442700

19. European Commission. Commission Regulation (EC) No 1126/2007. of 28 September 2007 Amending Regulation (EC) no 1881/2006 Setting Maximum Levels for Certain Contaminants in Foodstuffs as Regards Fusarium toxins in maize and maize products. Off J Eur Union 2007;255:14-7. https://doi.org/10.5771/9783845266466-1032-1

20. Wu F. Mycotoxin reduction in Bt corn: Potential economic, health, and regulatory impacts. Transgenic Res. 2006;15:27789. https://doi.org/10.1007/s11248-005-5237-1 PMid:16779644

21. Prietto L, Moraes PS, Kraus RB, Meneghetti V, Fagundes CA, Furlong EB. Post-harvest operations and aflatoxin levels in rice (Oryza sativa). Crop Protect 2015;78:172-7. https://doi. org/10.1016/j.cropro.2015.09.011

22. Saudi Food and Drug Authority. Contaminants and Toxins in Food and Feed; 2019. Available from: https://www.resources. selerant.com/food-regulatory-news/saudi-governmentpublishes-a-new-draft-standard-on-contaminants-and-toxins.

23. AOAC Official Methods of analysis of AOAC International. Published $19^{\text {th }}$ edby AOAC International Suite 500481 North 
Fredrick Avenue Gaithersburg, Maryland, USA. Ch. 49. Washington: Association of Official Analytical Chemists; 2012.

24. Dragacci S, Grosso F, Gilbert J. Immunoaffinity column cleanup with liquid chromatography for determination of aflatoxin M1 in liquid milk: Collaborative study. J AOAC Int. 2001;84(2):437-43. https://doi.org/10.1093/jaoac/84.2.437

PMid:11324608

25. Deabes MM, Aboelsoud $\mathrm{NH}$, Taha L. In vitro Inhibition of growth and aflatoxin $\mathrm{B}_{1}$ production of Aspergillus flavus strain (ATCC 16872) by various medicinal plant essential oils. Maced J Med Sci. 2011;4(4):345-50. https://doi.org/10.3889/ mjms.1857-5773.2011.0190

26. Deabes MM, Darwish HR, Abdel-Aziz KB, Farag IM, Nada SA, Tewfik NS. Protective effects of Lactobacillus rhamnosus GG on aflatoxins-induced toxicities in male albino mice. J Environ Anal Toxicol. 2012;2:2-9. https://doi.org/10.4172/2161-0525.1000132

27. Eshak MG, Deabes MM, Farrag AH, Farag IM, Stino FK. Effect of ozone-treated aflatoxin contaminated diets on DNA damage, expression of androgen and androgen receptor genes, and histopathological changes in Japanese quail. Glob Vet. 2013;11(1):1-13.

28. Abou El-Soud NH, Deabes MM, Abou El-Kassem L, Khalil M. Chemical composition and antifungal activity of Ocimum basilicum L. essential oil. Maced J Med Sci. 2015;3(3):374-9. https://doi.org/10.3889/oamjms.2015.082 PMid:27275253

29. a. Deabes MM, Wagdy KB, Attallah AG, El-Desouky TA, Naguib K. Impact of silver nanoparticles on gene expression in Aspergillus flavus producer aflatoxin B1. Maced J Med Sci. 2018;6(4):600-5. https://doi.org/10.3889/oamjms.2018.117

PMid:29731923. b. Deabes MM, Amra HA, El-Damaty EM, Rowayshed GH. Natural Co-occurrence of aflatoxins, cyclopiazonic acid, and their production by Aspergillus flavus isolates from corn grown in Egypt. Adv Clin Toxicol. 2018;3(3):1 10. https://doi.org/10.23880/act-16000136

30. International Conference on Harmonization. Harmonized tripartite guideline, validation of analytical procedures, text and methodology. Geneva, Switzerland: International Conference on Harmonization; 2006. p. 12e4. https://doi.org/10.1007/ springerreference_83218

31. NATA Technical Note 17. Guidelines for the Validation and Verification of Quantitative and Qualitative Test Methods. Australia: National Association of Testing Authorities. 2013. p. 17-8.

32. IBM Corp. IBM SPSS Statistics for Windows, Version 22.0 . Armonk, NY: IBM Corp; 2013.

33. Scott PM, Lawrence GA. Determination of aflatoxins in beer. J AOAC Int. 1997;80(6):1229-34. PMid:9419863

34. Stroka J, Anklam E. New strategies for the screening and determination ofaflatoxinsandthe detection of aflatoxin-producing moulds in food and feed. Trends Anal Chem. 2002;21(2):90-5. https://doi.org/10.1016/s0165-9936(01)00133-9

35. Stoloff L. Aflatoxins an overview. In: Rodricks JV, Hesseltine CW, Mehlman MA, editors. Mycotoxins in Human and Animal Health. Park Forest South, Illinois: Pathotos Publishers; 1977. p. 7-28.

36. Shank RC, Gordon JE, Wogan GN, Nondasuta A, Subhamani B. Dietary aflatoxins and human liver cancer. III. Field survey of rural Thai families for ingested aflatoxins. Food Cosmet Toxicol 1972;10:71-84. https://doi.org/10.1016/ s0015-6264(72)80048-8

37. Krishnamachari KA, Bhat RV, Nagarajan V, Tilak TB. Investigations into an outbreak of hepatitis in parts of Western India. Indian J Med Res. 1975;63(7):1036-48.

PMid:1213790

38. Turner PC, Mendy M, White H, Fortuin M, Hall AJ, Wild CP. Hepatitis B infection and aflatoxin biomarker levels in Gambian children. Trop Med Int Health. 2000;5(12):837-41. https://doi. org/10.1046/j.1365-3156.2000.00664.x

\section{PMid:11169271}

39. European Food Safety Authority. Opinion of the scientific panel on contaminants in the food chain on a request from the commission related to the potential increase of consumer health risk by a possible increase of the existing maximum levels for aflatoxins in almonds, hazelsnuts and pistachios and derived products. EFSA J. 2007;446:1-127. https://doi.org/10.2903/j. efsa.2007.446

40. Turner PC, Sylla A, Diallo MS, Castegnaro JJ, Hall AJ, Wild CP. The role of aflatoxins and hepatitis viruses in the etiopathogenesis of hepatocellular carcinoma: A basis for primary prevention in Guinea Conakry, West Africa. J Gastroent Hep. 2002;17:441-8. https://doi.org/10.1046/j.1440-1746.17. s4.7.x

PMid: 12534775

41. Turner PC, Moore SE, Hall AJ, Prentice AM, Wild CP. Modification of immune function through exposure to dietary aflatoxin in Gambian children. Environ Health Pers. 2003;111:217-20. https://doi.org/10.1289/ehp.5753

42. Luttfullah G, Hussain A. Studies on contamination level of aflatoxins in some dried fruits and nuts of Pakistan. Food Control. 2011;22:426-9. https://doi.org/10.1016/j.foodcont.2010.09.015

43. Mojtahedi H, Rabie CJ, Lubben A, Steyn M, Danesh D. Toxic aspergilli from pistachio nuts. Mycopathol. 1979;67(2):123-7. PMid:481560

44. Pittet A. Natural occurrence of mycotoxins in foods and feeds-an updated review. Rev Med Vet. 1998;149:479-92.

45. Abdel-Hafez, A $2^{\text {nd }}$, Saber SM. Mycoflora and mycotoxin of hazelnut (Corylus avellana L.) and walnut (Juglans regia L.) seeds in Egypt. Zentralblatt Mikrobiol. 1993;148:137-47. https:// doi.org/10.1016/s0232-4393(11)80117-4

46. Singh PK, Shukla AN. Survey of mycoflora counts, aflatoxin production and induced biochemical changes in walnut kernels. J Stored Prod Res. 2008;44:169-72. https://doi.org/10.1016/j. jspr.2007.10.001

47. Denning DW. Aflatoxin and human diseases. In: Davies DM, deGlanville $\mathrm{H}$, editors. Adverse Drug Reactions and Acute Poisoning Reviews. Vol. 4. Oxford, UK: Oxford University Press; 1987. p. 175-209.

48. Payne GA, Hagler WM, Adkins CR. Aflatoxin accumulation in inoculated ears of field-grown maize. Plant Dis. 1998;72:422-4. https://doi.org/10.1094/pd-72-0422

49. Payne GA. Aflatoxin in maize. Crit Rev Plant Sci. 1992;10(5):423-40.

50. Rachaputi NR, Wright GC, Kroschi S. Management practices to minimise pre-harvest aflatoxin contamination in Australian groundnuts. Austr J Exp Agric. 2002;42:595-605. https://doi. org/10.1071/ea01139

51. Temba MC, Njobeh PB, Kayitesi E. Storage stability of maize groundnut composite flours and an assessment of aflatoxin B1 and ochratoxin a contamination in flours and porridges. Food Control. 2017;71:178-86. https://doi.org/10.1016/j. foodcont.2016.06.033

52. Martinez-Miranda MM, Rosero-Moreano M, Taborda-Ocampo G Occurrence, dietary exposure and risk assessment of aflatoxins in arepa, bread and rice. Food Control. 2019;98:359-66. https:// doi.org/10.1016/j.foodcont.2018.11.046

53. Andrade PD, Caldas ED. Aflatoxins in cereals: Worldwide occurrence and dietary risk assessment. World Mycotoxin J. 2015;8:415-31. https://doi.org/10.3920/wmj2014.1847

54. Tanaka K, Sago Y, Zheng Y, Nakagawa H, Kushiro M Mycotoxinsin rice. Int J Food Microbiol. 2007;119(1-2):59-66. PMid:17913273. 
55. Palumbo R, Crisci A, Venâncio A, Abrahantes JC, Dorne JL, Battilani $\mathrm{P}$, et al. Occurrence and co-occurrence of mycotoxins in cereal-based feed and food microorganisms. Microorganisms. 2020;8:741-17. https://doi.org/10.3390/ microorganisms 8010074

PMid:31947721

56. Atanda SA, Pessu PO, Agoda S, Isong IU, Adekalu OA, Echendu MA. Fungi and mycotoxins in stored foods. Afr J Microbiol Res. 2011;5(25):4373-82. https://doi.org/10.5897/ajmr11.487

57. Smith LE, Stasiewicz M, Hestrin R, Morales L, Mutiga S, Nelson RJ. Examining environmental drivers of spatial variability in aflatoxin accumulation in Kenyan maize: Potential utility in risk prediction models. Afr J Food Agric Nutr Dev. 2016;16(3):11086-5. https://doi.org/10.18697/ajfand.75.ilri09

58. Reiter E, Vouk F, Bohm J, Razzazi-Fazeli E. Aflatoxins in rice a limited survey of products marketed in Austria. Food Control. 2010;21:988-91. https://doi.org/10.1016/j. foodcont.2009.12.014

59. Sarker M, Ibrahim M, Aziz N, Punan M. Application of simulation in determining suitable operating parameters for industrial scale fluidized bed dryer during drying of high impurity moist paddy. J Stored Prod Res. 2015;61:76-84. https://doi. org/10.1016/j.jspr.2014.12.004 